\title{
The frequent BRCAI mutation I I 35insA has multiple origins: a haplotype study in different populations
}

\author{
Teresa M Rudkin ${ }^{\dagger 1}$, Nancy Hamel ${ }^{\dagger 2}$, Maria Galvez ${ }^{2}$, Frans Hogervorst ${ }^{3}$, \\ Johan JP Gille4, Pål Møller ${ }^{5}$, Jaran Apold ${ }^{6}$ and William D Foulkes*1,2,7
}

\begin{abstract}
Address: ${ }^{1}$ Department of Human Genetics, McGill University, Montreal, Canada, ${ }^{2}$ Department of Medicine and Research Institute, McGill University Health Centre, Montreal, Canada, ${ }^{3}$ Family Cancer Clinic, Department of Pathology, The Netherlands Cancer Institute, Amsterdam, The Netherlands, ${ }^{4}$ Department of Clinical Genetics, VU University Medical Center, Amsterdam, The Netherlands, ${ }^{5}$ Department of Cancer Genetics, The Norwegian Radium Hospital, N-0310 Oslo, Norway, ${ }^{6}$ Center of Medical Genetics and Molecular Medicine, Haukeland University Hospital, Bergen, Norway and ${ }^{7}$ Cancer Prevention Centre, Sir Mortimer B Davis-Jewish General Hospital, McGill University, Montreal, Canada

Email: Teresa M Rudkin - teresa@mrs.mni.mcgill.ca; Nancy Hamel - nancy.hamel@mail.mcgill.ca; Maria Galvez - maria.galvez@mail.mcgill.ca; Frans Hogervorst - f.hogervorst@nki.nl; Johan JP Gille - jjg.gille@vumc.nl; Pål Møller - pal.moller@medisin.uio.no; Jaran Apold - jaran.apold@helse-bergen.no; William D Foulkes* - william.foulkes@staff.mcgill.ca

* Corresponding author †Equal contributors
\end{abstract}

Published: 01 March 2006

BMC Medical Genetics 2006, 7:15 doi:10.1 186/147|-2350-7-15
Received: 09 August 2005

Accepted: 0 I March 2006

This article is available from: http://www.biomedcentral.com/l47/-2350/7//5

(C) 2006 Rudkin et al; licensee BioMed Central Ltd.

This is an Open Access article distributed under the terms of the Creative Commons Attribution License (http://creativecommons.org/licenses/by/2.0), which permits unrestricted use, distribution, and reproduction in any medium, provided the original work is properly cited.

\begin{abstract}
Background: Analysis of the chromosomal background upon which a mutation occurs can be used to reconstruct the origins of specific disease-causing mutations. The relatively common BRCAI mutation, II35insA, has been previously identified as a Norwegian founder mutation. We performed haplotype analysis of individuals from breast and ovarian cancer families from four different ethnic backgrounds who had been identified as carriers of the BRCA I: I I35insA mutation.

Methods: Four microsatellite markers (DI7S855, DI7SI322, DI7SI323 and DI7SI325) located within or near the BRCAI gene were genotyped in mutation carriers from 6 families of French Canadian, Italian and Dutch descent. Haplotypes were inferred from the genotype data and compared between these families and with the previously reported Norwegian founder haplotype.

Results: The II 35insA mutation was found to occur on three distinct haplotype backgrounds. The families from Norway shared a distinct haplotype while the families of French Canadian, Italian, and Dutch descent were found to occur on one of two additional, distinct backgrounds.

Conclusion: Our results indicate that while the Norwegian haplotype including II35ins A represents an ancient Norwegian mutation, the same mutation has occurred independently in the other populations examined. In centres where targeted mutation testing is performed, exclusively or prior to gene sequencing, our findings suggest that this recurring mutation should be included in targeted mutation panels, irrespective of the ethnic origin of the persons tested.
\end{abstract}

\section{Background}

Analysis of the chromosomal background upon which a mutation occurs can be used to reconstruct the origins of specific disease-causing mutations. Mutations that are seen repeatedly on a common haplotype are likely to have descended from a common ancestor, and are referred to as "founder mutations". Several founder mutations of the breast and ovarian cancer susceptibility gene BRCA1 have 
Table I: Haplotype analysis of unrelated, BRCA I I I35insA carriers

\begin{tabular}{lccccccc}
\hline Marker & Norway & B856 & B050 & NKI & Mon270 & MonDS & Mon I467 \\
\hline DI7S1325 & 218 & 216 & 216 & 216 & 216 & 198 & 198 \\
DI7S1323 & 162 & 158 & 158 & 158 & 158 & 150 & 150 \\
DI7S1322 & 131 & 125 & 125 & 125 & 125 & 122 & 122 \\
DI7S855 & 150 & 146 & 146 & 146 & 146 & 150 & 150 \\
\hline
\end{tabular}

Norway: Six Norwegian families [8]

B856, B050, NKI: Dutch families (Amsterdam)

Mon270, MonDS: Italian families (Montreal)

Mon 1467: French Canadian (Montreal)

been identified in individuals of many different ancestries, including families of Ashkenazi Jewish (187delAG, 5385insC) [1], French Canadian (C4446T, 2953del3+C) [2,3], Dutch (2804delAA and Alu-mediated deletions encompassing exons 13 and 22) [4,5], and Polish (5385insC, C61G, 4153delA) [6] origins. The BRCA1 mutation 1135insA (HGVS nomenclature: c.1135_1136insA) is a frameshift mutation occurring in exon $1 \overline{1}$. It has previously been identified as one of four founder mutations originating from the Eastern population of Norway $[7,8]$. In one series, approximately $1 \%$ of Norwegian women under the age of 70 years with ovarian cancer carried this mutation [9] and it accounts for 20\% of all BRCA1/2 mutation carriers demonstrated by DNA testing today in Norway (Møller, unpublished data). This mutation appears on an ancient haplotype, and the age of the 1135 ins A mutation has not yet been determined. All tested Norwegian individuals with the 1135insA mutation carry the same flanking markers (Møller, unpublished data).

In contrast to other Norwegian founder mutations, the 1135insA mutation has also been reported in other ethnic groups. The mutation has been catalogued 44 times to date in the Breast Cancer Information Core (BIC) database [10] and has been reported to occur in populations throughout Europe including Spain, Norway, the Netherlands, Austria, Italy, as well as in Latin America and North
America. These observations raise the question whether BRCA1: 1135insA is an ancient mutation that has arisen once, or whether it has occurred several times in human history. The issue is relevant when ethnic-specific mutation panels are used as a pre-screen prior to complete exon-by-exon evaluation of $B R C A 1 / 2$. To address this question, we performed haplotype analysis of the BRCA1 region in unrelated carrier families of Norwegian, Italian, French Canadian, and Dutch descent.

\section{Methods}

Families containing individuals carrying the BRCA1:1135insA mutation were recruited into the study via high-risk cancer genetics clinics at McGill University, Montreal, Quebec, Canada, VU University Medical Center and the National Cancer Institute, Amsterdam, The Netherlands, and The Department of Cancer Genetics, Olso, Norway. Appropriate institutional informed consent guidelines were followed for all recruited patients. All mutation identification was performed by direct sequencing in the laboratories of the primary investigators at McGill University, Montreal; the National Cancer Institute, Amsterdam and Haukeland University Hospital, Bergen. Polymorphic microsatellite repeat markers located within (D17S855, D17S1322, D17S1323) and adjacent to (D17S1325) the BRCA1 locus were used for haplotype analysis. We amplified 100ng of genomic DNA from each subject by PCR for each marker using radioactively

Table 2: Primers used to generate the haplotype

\begin{tabular}{|c|c|c|c|c|c|}
\hline Marker & $\begin{array}{c}\text { Chromosome } 17 \\
\text { position }\end{array}$ & Forward Primer & Reverse Primer & $\mathbf{T}_{\mathrm{m}}\left({ }^{\circ} \mathrm{C}\right)$ & Other \\
\hline DI7S855 & $38,458,470$ & $\begin{array}{l}\text { GGATGGCCTTTTA } \\
\text { GAAAGTGG }\end{array}$ & $\begin{array}{l}\text { ACACAGACTTGTC } \\
\text { CTACTGCC }\end{array}$ & 57 & $5 \%$ DMSO $†$ \\
\hline DI7SI322 & $38,465,161$ & $\begin{array}{c}\text { CTAGCCTGGGCAA } \\
\text { CAAACGA }\end{array}$ & $\begin{array}{l}\text { GCAGGAAGCAGG } \\
\text { AATGGAAC }\end{array}$ & 60 & -- \\
\hline DI7SI323 & $38,491,793$ & $\begin{array}{c}\text { TAGGAGATGGATT } \\
\text { ATTGGTG }\end{array}$ & $\begin{array}{l}\text { AAGCAACTTTGCA } \\
\text { ATGAGTG }\end{array}$ & 60 & -- \\
\hline DI7SI325 & $38,891,165$ & $\begin{array}{c}\text { AAAGGTGGCAATT } \\
\text { CACAGTTG }\end{array}$ & $\begin{array}{l}\text { GTGATAAAACTCA } \\
\text { GTGGTACTC }\end{array}$ & $65-55^{*}$ & $\mathrm{I} \times \mathrm{Q}$ solution \\
\hline
\end{tabular}

All reactions were amplified for 35 cycles $\left[30 \mathrm{~s} @ 95^{\circ} \mathrm{C}, 30 \mathrm{~s} @ \mathrm{~T}_{\mathrm{m}}, 30 \mathrm{~s} @ 72^{\circ} \mathrm{C}\right]$ and contained $200 \mathrm{uM}$ dCTP/dGTP/dTTP, 24 uM dATP, 10 uCi $\alpha^{35} \mathrm{~S}$ dATP, I $\times$ PCR buffer and $0.5 \mathrm{U}$ of HotStar Taq DNA polymerase (QIAGEN). †Dimethyl Sulfoxide. ${ }^{*} \mathrm{~T}_{\mathrm{m}}$ starting at $65^{\circ} \mathrm{C}$ and decreasing by I ${ }^{\circ} \mathrm{C}$ per cycle for 10 cycles, followed by 25 cycles at $55^{\circ} \mathrm{C}$; Q solution from QIAGEN. 
labelled nucleotides (primer sequences, marker positions and PCR conditions are given in Table 2). PCR products were separated on $5 \%$ acrylamide/urea denaturing gels at $70 \mathrm{~W}$ for $1 \mathrm{~h} 45$ and alleles were visualized by autoradiography.

\section{Results \\ Clinical description}

Haplotype analysis was performed on selected cases from three families recruited from the Hereditary Cancer Clinic of McGill University in Montreal (2 Italian, 1 French Canadian), and three Dutch families from the Netherlands Cancer Institute (NKI) in Amsterdam. Haplotype analysis was previously done in Norway on six families [8]. The index patients were referred because of a personal and/or family history of breast or ovarian cancer and were subsequently found to be carriers of the BRCA1: 1135insA mutation. Although not discussed above, the family histories of these cases are consistent with this mutation being highly penetrant for both breast and ovarian cancer. The family histories of the Norwegian families have been described previously [8].

\section{Haplotype analysis}

The results of the haplotype analyses are shown in Table 1. The 1135insA mutation was found to occur on three distinct haplotype backgrounds. The families from Norway had a unique haplotype (218-162-131-150). The three Dutch families shared a common haplotype (216158-125-146), which was also found in one Italian family from Montreal. The remaining two families from Montreal - one family of French Canadian descent and the other of Italian descent - shared a third distinct haplotype (198-150-122-150).

\section{Discussion}

The unique haplotype common to all 6 Norwegian families (218-162-131-150) indicates 1135insA is an ancient founder mutation in the Norwegian population. The Netherlands contained a major port during the Middle Ages with outposts to ports elsewhere in Europe. By the seventeenth century, Amsterdam was the biggest trading port of northern commodities and grain to the Mediterranean [12]. One can hypothesize that these trade routes are one means by which a Norwegian founder mutation, on its original haplotype, may have been passed to various Mediterranean countries and hence to North America. Identification of two other, clearly distinct haplotypes in the families examined here suggests, however, that the mutation likely occurred independently in other populations.

In the BIC database [10], the 1135insA mutation is the $12^{\text {th }}$ most common frameshift mutation occurring in $B R C A 1$. Since our results suggest it does not have a single origin, it may be a relative "hot spot" within the BRCA1 gene. Recombination events or marker mutations could theoretically account for haplotype divergence from a single, original haplotype but are not likely explanations here. Marker D17S855 in intron 20 is only $6.7 \mathrm{~kb}$ from D17S1322 in intron 19, and D17S1322 is $26 \mathrm{~kb}$ from D17S1323 in intron 12. Markers in such close proximity are unlikely to undergo extensive recombination events. While recombination could conceivably have occurred between D17S1325, located $400 \mathrm{~kb}$ upstream from D171323, and the intragenic markers, the haplotypes observed in our families are not consistent with this scenario. In particular, recombination suppression seems to be present in the genomic region that includes BRCA1, making recombination in this region an even more unlikely explanation [13]. On the other hand, the DNA sequence surrounding the mutation includes a run of seven consecutive adenines. BRCA1:1135insA is an insertion of one A anywhere in the poly-A area in which it occurs - the position 1135 is but a convention for nomenclature. This poly-A region may thus create a hot-spot within BRCA1 for replication errors. Alternatively, the same poly-A stretch may have induced repetitive gene conversions or cross-overs.

The BRCA2 mutation 8765 delAG is another example of an "ancient" mutation that has been shown to have recurred in different populations. First described as a founder mutation in Sardinia [14], it has been found on different haplotype backgrounds in different populations, including French Canadians and Yemenite Jews [15]. The mutation occurs within a stretch of DNA where 4 consecutive AGs can be found. It is likely that the genomic context in which the BRCA1: 1135insA and BRCA2: 8765delAG mutations occur favours errors of small insertions and deletions.

\section{Conclusion}

We set out to determine whether BRCA1: 1135insA is an ancient mutation that has arisen once, or whether it has recurred several times in human history. Our finding that 1135insA exists on several, clearly distinct haplotypes and the fact that it is found in a homopolymer tract suggests it may have appeared independently several times in the human genome. A clinically relevant implication of our findings is that this recurrent mutation should probably be included in targeted BRCA1 mutation screening panels in any population, irrespective of ethnic origin. When the ethnic origin is clearly defined, founder mutation panels can, and are used in several centres. A "pre-screen" based on the most frequent BRCA1/2 mutations seen in the BIC could also be considered as a first step, prior to complete gene sequence analysis. 


\section{Competing interests}

The author(s) declare that they have no competing interests.

\section{Authors' contributions}

TMR wrote the drafts and produced the final manuscript. $\mathrm{NH}$ did most of the genotyping and haplotype reconstruction and assisted in writing the manuscript. MG carried out some of the genotyping. FH did some genotyping and contributed to the writing of the manuscript. JJPG provided cases. PM provided cases and assisted in the writing of the manuscript. JA provided cases and provided comment on the manuscript. WDF conceived of and managed the project, provided cases, and assisted in drafting the manuscript. All authors read and approved the final manuscript.

\section{Acknowledgements}

We wish to thank Lidia Kasprzak M.Sc. and Karlene Australie M.Sc. for genetic counselling of the Montreal families and to Cora Aalfs, MD, Yolande van Wever MD, and Louise de Lange for genetic counselling of the Dutch families. This study was funded by a grant to WDF from the Canadian Genetic Diseases Network.

\section{References}

I. Tonin P, Serova O, Lenoir G, Lynch H, Durocher F, Simard J, Morgan $\mathrm{K}$, Narod S: BRCAI mutations in Ashkenazi Jewish women. AJHG 1995, 57:189.

2. Tonin PN, Mes-Masson AM, Futreal PA, Morgan K, Mahon M, Foulkes WD, Cole DE, Provencher D, Ghadirian P, Narod SA: Founder BRCAI and 2 mutations in French Canadian breast and ovarian cancer families. AJHG 1998, 53:|34|-5|.

3. Durocher F, Tonin P, Shattuck-Eidens D, Skolnick M, Narod SA, Simard J: Mutation analysis of the BRCA I gene in 23 families with cases of cancer of the breast, ovary, and multiple other sites. J Med Genet 1996, 33:8I4-19.

4. Peelen T, van Vliet M, Petrij-Bosch A, Mieremet R, Szabo C, van den Ouweland AM, Hogervorst F, Brohet R, Ligtenberg MJ, Teugels E, van der Luijt R, van der Hout AH, Gille JJ, Pals G, Jedema I, Olmer R, van Leeuwen I, Newman B, Plandsoen M, van der Est M, Brink G, Hageman S, Arts PJ, Bakker MM, Devilee P: A high proportion of novel mutations in BRCAI with strong founder effects among Dutch and Belgian hereditary breast and ovarian cancer families. Am J Hum Genet 1997, 60:104I-1049.

5. Petrij-Bosch A, Peelen T, van Vliet M, van Eijk R, Olmer R, Drusedau M, Hogervorst FB, Hageman S, Arts PJ, Ligtenberg MJ, Meijers-Heijboer H, Klijn JG, Vasen HF, Cornelisse CJ, van't Veer LJ, Bakker E, van Ommen G], Devilee P: BRCAI genomic deletions are major founder mutations in Dutch breast cancer patients. Nat Genet 1997, I7:34|-345.

6. Gorski B, Jakubowska A, Huzarski T, Byrski T, Gronwald J, Grzybowska E, Mackiewicz A, Stawicka M, Bebenek M, Sorokin D, FiszerMaliszewska L, Haus O, Janiszewska H, Niepsuj S, Gozdz S, Zaremba L, Posmyk M, Pluzanska M, Kilar E, Czudowska D, Wasko B, Miturski R, Kowalczyk JR, Urbanski K, Szwiec M, Koc J, Debniak B, Rozmiarek A, Debniak T, Cybulski C, Kowalska E, Toloczko-Grabarek A, Zajaczek S, Menkiszak J, Medrek K, Masojc B, Mierzejewski M, Narod SA, Lubinski J: A high proportion of founder BRCAI mutations in Polish breast cancer families. Int / Canc 2004, I 1 0:683-6.

7. Møller P, Borg A, Heimdal K, Apold J, Vallon-Christersson J, Hovig E, Maehle L, Norwegian Inherited Breast Cancer Group, Norwegian Inherited Ovarian Cancer Group: The BRCAI syndrome and other inherited breast or breast-ovarian cancers in a Norwegian prospective series. Eur J Cancer 200I, 37:1027-1032.

8. Moller P, Heimdal K, Apold J, Fredriksen A, Borg A, Hovig E, Hagen A, Hagen B, Pedersen JC, Maehle L, Norwegian Inherited Breast Cancer Group, Norwegian Inherited Ovarian Cancer Group: Genetic epidemiology of BRCAI mutations in Norway. Eur J Canc 200I, 37:2428-2434.

9. Dørum A, Hovig E, Tropé, Inganas M, Moller P: Three per cent of Norwegian ovarian cancers are caused by BRCAI 1675delA or II 35insA. Eur J Cancer 1999, 35:779-78I.

10. [http://research.nhgri.nih.gov/bic/].

II. Heimdal K, Mæhle L, Apold J, Pedersen JC, Moller P: The Norwegian founder mutations in BRCAI: high penetrance confirmed in an incident cancer series and differences observed in the risk of ovarian cancer. Eur J Cancer 2003, 39:2205-22I3.

12. Encyclopædia Britannica. 2003.

13. Liu X, Barker DF: Evidence for effective suppression of recombination in the chromosome 17q2I segment spanning RNU2-BRCAI. AJHG 1999, 64:1427-39.

14. Pisano M, Cossu A, Persico I, Palmieri G, Angius A, Casu G, Palomba G, Sarobba MG, Rocca PC, Dedola MF, Olmeo N, Pasca A, Budroni M, Marras V, Pisano A, Farris A, Massarelli G, Pirastu M, Tanda F: Identification of a founder BRCA2 mutation in Sardinia. Brit J Cancer 2000, 82:553-9.

15. Manning AP, Abelovich D, Ghadirian P, Lambert JA, Frappier D, Provencher D, Robidoux A, Peretz T, Narod SA, Mes-Masson AM, Foulkes WD, Wang T, Morgan K, Fujiwara TM, Tonin PN: Haplotype analysis of BRCA2 8765delAG mutation carriers in French Canadian and Yemenite Jewish hereditary breast cancer families. Human Heredity 2001, 52: I 16-20.

\section{Pre-publication history}

The pre-publication history for this paper can be accessed here:

http://www.biomedcentral.com/1471-2350/7/15/prepub

Publish with Bio Med Central and every scientist can read your work free of charge

"BioMed Central will be the most significant development for disseminating the results of biomedical research in our lifetime. "

Sir Paul Nurse, Cancer Research UK

Your research papers will be:

- available free of charge to the entire biomedical community

- peer reviewed and published immediately upon acceptance

- cited in PubMed and archived on PubMed Central

- yours - you keep the copyright 